\title{
Epidemiological and molecular characteristics of HIV-1 infection among female commercial sex workers, men who have sex with men and people living with AIDS in Paraguay
}

\author{
Características epidemiológicas e moleculares da infecção por HIV-1 \\ entre as mulheres que trabalham no comércio do sexo, entre \\ homens que mantém relações sexuais com homens e nas \\ pessoas convivendo com AIDS no Paraguai
}

\author{
Nicolas Aguayo ${ }^{1}$, Victor Alberto Laguna-Torres ${ }^{2}$, Margarita Villafane ${ }^{1}$, Alma Barboza $^{1}$, Liliana Sosa ${ }^{1}$, \\ Gloria Chauca ${ }^{2}$, Gladys Carrion ${ }^{2}$, Beatriz Coenca ${ }^{1}$, Juan Perez ${ }^{2}$, Adolfo Galeano ${ }^{3}$, \\ Christian T. Bautista ${ }^{2}$, Jose L. Sanchez ${ }^{4}$, Jean K. Carr ${ }^{5}$ and Tadeusz Kochel ${ }^{2}$
}

\begin{abstract}
An HIV seroprevalence and molecular study was conducted among 935 subjects: 723 female commercial sex workers, 92 men who have sex with men and 120 HIV-positive volunteers. The reported injection drug use rates were $0.7 \%$ in female commercial sex workers and $3 \%$ in men who have sex with men. Sexually transmitted infections were reported in 265 (37\%) of the female commercial sex workers and 38 (41\%) of the men who have sex with men. A total of $20(2.8 \%)$ female commercial sex workers and $12(13 \%)$ men who have sex with men became HIV infected during the study period. A history of sexually transmitted infection increased the risk of subsequent HIV infection twofold (adjusted odds ratio of 2.5) among the female commercial sex workers, while cocaine use had an adjusted odds ratios of 6.61 among men who have sex with men. From 130 samples, and based on heteroduplex mobility assaying for the $e n v$ gene, with sequencing of part of pol and/or full genomes, subtype B was the predominant subtype identified (66\%); followed by subtype F (22\%) and subtype C (4\%). Recombinant CRF12-BF strains were identified in 6\% and CRF17_BF was identified in $2 \%$.
\end{abstract}

Key-words: HIV/AIDS. Paraguay. Epidemiology. HIV genotypes. Developing countries.

\section{RESUMO}

Um estudo de soroprevalência e de avaliação molecular do HIV foi realizado com 935 indivíduos: 723 mulheres que trabalhavam no comércio do sexo, 92 homens que mantinham relações sexuais com outros homens e com 120 voluntários HIV-positivos. 0 relato de uso de drogas injetáveis foi de $0,7 \%$ nas mulheres que trabalhavam no comércio do sexo e de $3 \%$ nos homens que mantinham relações sexuais com outros homens. Infecções sexualmente transmitidas foram relatadas por 265 (37\%) das mulheres que trabalhavam no comércio do sexo e em 38 (41\%) dos homens que mantinham relações sexuais com homens. Um total de 20 (2,8\%) mulheres que trabalhavam no comércio do sexo e 12 (13\%) homens que mantinham relações sexuais com homens se infectou com HIV durante o período do estudo. História prévia de infecção sexualmente transmitida aumentou em duas vezes o risco de infecção subseqüente por HIV (odds ratio ajustado de 2,5) entre as mulheres que trabalhavam no comércio do sexo, enquanto cocaína apresentou odds ratio ajustado de 6,61 entre os homens que mantinham relações sexuais com outros homens. De 130 amostras, com base no ensaio da mobilidade heteroduplex para o gene env, com sequenciamento de parte do pol e/ou genomas completos, o subtipo B foi o subtipo mais identificado (66\%); seguido pelo subtipo F (22\%) e subtipo C (4\%). Cepas recombinantes CRF12-BF foram identificadas em 6\% e CRF17_BF foi identificada em $2 \%$.

Palavras-chaves: HIV/AIDS. Paraguai. Epidemiologia. Genótipos HIV. Países em desenvolvimento.

\footnotetext{
1. Ministry of Health Paraguay, Asunción, Paraguay. 2.U.S. Naval Medical Research Center Detachment Lima, Perú. 3. Instituto de Medicina Tropical, Ministry of Health Paraguay, Asunción, Paraguay. 4. Department of Defense Global Emerging Infections Surveillance and Response System, Lima, Perú. 5. Institute of Human Virology, University of Maryland School of Medicine, MD, USA.

This work was supported by Work Unit Number (WUN) No. 62787A.873.H.B0002.

Address to: Dr Nicolas Aguayo. PRONASIDA-Paraguay; Dr. Victor Alberto Laguna-Torres. Naval Medical Research Center Detachment. Lima, Perú.

e-mail: direccion@pronasida.gov.py; alberto.laguna@med.navy.mil

Recebido para publicação em: 12/07/2007

Aceito em: 19/05/2008
} 
The first case of the acquired immunodeficiency syndrome (AIDS) in Paraguay was reported in $1985^{6}$. Subsequently, the Paraguayan government created an interministerial commission to develop a program of action in order to prevent, detect and control new AIDS cases. Since 1990, the National AIDS/Sexually Transmitted Infection (STI) Control Program (PRONASIDA, initials in Spanish), under the direction of the Ministry of Public Health and Social Welfare, has been the principal entity in charge of Paraguay's response to AIDS. From 1986 to December 2005, a total of 3,071 HIV-positive individuals were reported, including 1,342 AIDS cases. Thus, the annual incidence rate is 3.86 per 100,000 inhabitants $^{9}$

New cases of human immunodeficiency virus (HIV) infection are concentrated in the capital city, Asuncion. High incidence rates are also found in the Central department (which has a population of internal migrants) and the border departments with Brazil and Argentina (with an intense flow of individuals for commercial reasons) ${ }^{9}$. Between 1985 and 1990, new cases of HIV infection came mainly from Asuncion and some cities in the Central department, such as Cordillera, Caaguazu and Alto Parana, along the heavily traveled Asuncion-Ciudad del Este highway. Subsequently, infection remained concentrated around Asuncion but is now extending to other regions, including Amambay Canindeyu (where much of the country's trade with Brazil is concentrated) as well as Paraguari, Misiones, and Itapua on the Asuncion-Encarnacion route (where there are commercial activities with Argentina) ${ }^{13}$. Most recently, new infections have been emerging in the west and northeast of the country.

The HIV epidemic in Paraguay has a low overall prevalence in the general population and is predominantly in urban areas. According to data provided by the Ministry of Health, the main mode of HIV transmission in Paraguay is sexual (80\%). Heterosexual transmission is increasing, comprising $75 \%$ of male cases and $57 \%$ of female cases. The second most important transmission mode is through blood and blood products $(6 \%)^{9}$. HIV prevalence is higher among males and has moderate incidence among injection drug users (IDUs.) Regarding diagnostic procedures, routine HIV screening has been available in Paraguay since the late 1980s.

The worldwide geographic distribution of HIV-1 subtypes varies greatly. Defining the genetic diversity of HIV-1 is a critical issue for epidemiological surveillance and vaccine development. Establishing the prevalent HIV-1 subtypes in Paraguay may assist with identifying suitable vaccine targets, as well as helping in tracking the course of the epidemic. Multiple recombinant viruses can be generated when individuals are infected with more than one HIV-1 subtype. These recombinants may be unique to that individual and are termed unique recombinant forms (URFs). Prospective follow-up of such individuals has shown that various recombinants and non-recombinants are distributed over time ${ }^{23}$ 11. Occasionally, one particular recombinant form may emerge as epidemiologically successful and begins to spread as a single form. When this happens, the recombinant is known as a circulating recombinant form $(\mathrm{CRF})^{2}{ }^{3}$. Each CRF has its own particular structure of recombination coordinates and, thus, has its own name. Current nomenclature numbers the CRFs sequentially as they are detected. At present, investigators have identified CRF01_AE to CRF16_A2D. Different recombinant subtypes have been identified in South America, mainly in Southern Cone countries like Argentina, Uruguay and Paraguay ${ }^{145}$.

The objective of this study was to assess two populations at high risk of HIV acquisition: female commercial sexual workers (FCSW) and men who have sex with men (MSM). We intended to evaluate the demographics and risk behavior among these groups in Paraguay. Another objective was to determine the distribution of subtypes and circulating recombinants of HIV-1 isolations in Paraguay, at NRMCD, Lima, Perú.

\section{MATERIAL AND METHODS}

Study population and participant enrollment. An observational HIV seroprevalence study, including a behavior survey, was conducted between August 2002 and March 2003 by the National AIDS/STI Control Program (PRONASIDA) and the Tropical Medicine Institute (IMT), both based in Asuncion. Genotyping laboratory procedures were conducted in 2004 and 2005.

Volunteer female commercial sex workers and men who have sex with men in the cities of Asuncion, Ciudad del Este, Encarnacion, PJ Caballero and Coronel Oviedo, aged 18 years or older, were invited to participate (Figure 1). Female commercial sex workers who reported sexual relations with at least one man in the preceding six months were enrolled. In addition, previously diagnosed HIV-positive patients identified at PRONASIDA in Asuncion were eligible to participate for the purposes of viral genotyping.

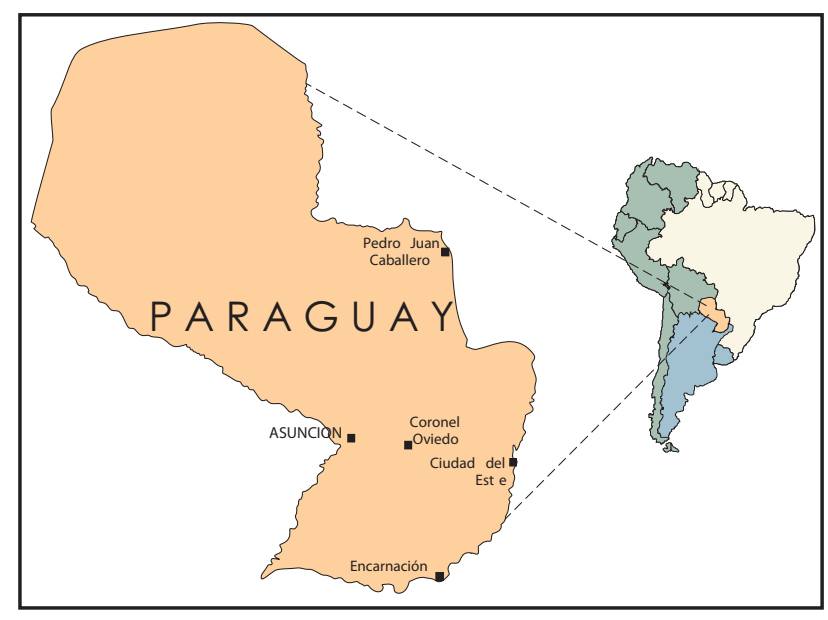

Figure 1 - Map of Paraguay showing the cities where this study was performed.

Participants were recruited on the streets or at discotheques, gay nightclubs, pubs, gymnasiums and adult cinemas from the aforementioned five cities. Pre and post-test counseling and blood sample collection were conducted at the PRONASIDA offices in a confidential manner by trained personnel. Interviewers explained the study objectives and procedures and obtained written informed 
consent. Only those subjects who were willing to participate and provided written informed consent were enrolled. The data collected included demographics and self-reported behavior with a risk of HIV acquisition. Emphasis was placed on collecting results using a single identifying code and ensuring that each participant received his own results. Seropositive individuals were referred to their local health clinic for appropriate medical care. Furthermore, these subjects were also referred to PRONASIDA for medical follow-up and HIV treatment, which was provided free of charge. In addition to counseling, periodic physical examinations were performed on-site. HIV-positive subjects were provided with prophylaxis for opportunistic infections and combination antiretroviral therapy when indicated. CD4+ lymphocyte counts were performed both at the United States Naval Medical Research Center Detachment in Lima, Peru (NMRCD-Lima), and PRONASIDA.

All consent forms and questionnaires were stored at PRONASIDA and IMT, which are entities within the Ministry of Health and Social Welfare of Paraguay. Copies were also maintained at NMRCD-Lima. A separate coded database containing questionnaire information, HIV-positive status and viral genotypes was maintained at the NMRCD-Lima Data Center for further analysis.

Serology and genotyping procedures. A blood sample was obtained to test for HIV antibodies by third-generation ELISA with confirmatory Western blot (WB) testing, which was performed at PRONASIDA. Viral DNA transcripts were extracted either from peripheral blood mononuclear cells (PBMC) or from blood spots collected from HIV-positive subjects.

Viral genotyping was performed either at NMRCD-Lima via heteroduplex mobility assay (HMA) or US Military HIV Research Program in the United States using amplification and sequencing of part of the pol gene or the nearly full genome.

Heteroduplex mobility assay was performed on all the samples. DNA was extracted from fresh blood (FB). Nested PCR on genomic DNA was performed on the $\mathrm{C} 2-\mathrm{C} 3$ region of the envelope using ED5/ED12 as the outer and ED31/ED33 as the inner primer, at the NMRCD-Lima laboratory. Then a number of samples were randomly selected for partial pol sequencing and those of interest were selected for nearly full genome sequencing. The pol region was amplified using Pro5F/RT3474R in the first round and Pro3F/ProRT in the second round. Nearly full-length sequences were produced using MSF12b and OFMR1 in the first round and using F2NST and UNINEF 7 in the second round. The amplified products were sequenced with Big Dye terminators using an $\mathrm{ABI}$ 3,100 automated sequencer (Applied Biosystems Inc, Foster City, CA, USA), assembled using the Sequencher software (Genecodes Inc, Ann Arbor, MI, USA) and examined in a multiple alignment with standard subtype references. Phylogenetic analyses were conducted by the Neighbor-joining method with Kimura's two-parameter model of distance calculation and a bootstrap computed with 100 replicates, using MEGA, v3.

Statistical analysis. Estimated numbers of 100 MSM subjects with an estimated HIV seroprevalence of $10 \%$ (error: 4\%; confidence level: 95\%) and 700 FCSW subjects for 5\% HIV seroprevalence (error: 2.5; confidence level: 95\%) were sought to achieve adequate statistical power.

The Chi-square test was used to evaluate associations and Student's "t" test was used to compare means. Associations of risk factors were expressed as adjusted odds ratios (AOR) with 95\% confidence intervals (CI). A multiple logistic regression analysis was carried out using LogXact version 7.0 (Cytel Inc, Cambridge, MA, USA).

\section{RESULTS}

Study population and prevalences. A total of 935 subjects were enrolled: 723 FCSW, 92 MSM and 120 volunteers with previous diagnoses of HIV infection. At entry, the mean age $\pm 1 \mathrm{SD}$ was 26 years \pm 7.2 for FCSW and $25 \pm 6.9$ for MSM. A lower level of education was documented among FCSW (63\% had completed elementary school) than among MSM (70\% had completed high school). Both populations were predominantly unmarried (66\% of FCSW and $80 \%$ of MSM) and Paraguayan (95\% of FCSW and $97 \%$ of MSM). Brazilians and Bolivians were the most frequent non-Paraguayan FCSW. Other nationalities included Chileans, Bolivians and Uruguayans (Table 1). Only 64\% of FCSW and $28 \%$ of MSM reported consistent condom use during sexual encounters with occasional partners. Among MSM, sometimes was the most frequent frequency of condom use reported $(58 \%$ of participants). A high frequency of irregular condom use was observed (i.e. never or sometimes) with regular partners in $36 \%$ of MSM and $74 \%$ of FCSW.

Knowledge of the risk factors for HIV transmission was assessed by questionnaire. A total of 620 (86\%) of FCSW knew that wearing condoms would reduce the risk of HIV transmission. On the other hand, 187 (26\%) of FCSW accepted more money to allow clients not to use condoms and 255 (35\%) did not always use condom with clients. In addition, 535 (74\%) knew that blood transfusions were a risk factor for HIV. On the other hand, only 48 (7\%) of FCSW knew that sharing needles and syringes increased the risk of transmission.

New HIV infections were diagnosed in $20(2.8 \%$; $95 \% \mathrm{CI}=$ 1.7-4.2) of the FCSW participants and in $12(13 \%$; $95 \% \mathrm{CI}=6.9$ 21.7) of the MSM participants. Injection drug use was reported by five FCSW $(0.7 \%)$ and three MSM (3\%). Non-injectionassociated illegal drug use (marijuana) was found to be relatively frequent, with $41 \%$ of MSM and 13\% of FCSW reporting its use. Overall, illegal drug use was reported by 45 (48.9\%) of the MSM participants and $120(16.6 \%)$ of the FCSW participants. Use of cocaine was almost four times more frequent among MSM (26\%) than among FCSW (7\%). A total of 39\% of MSM reported sexual intercourse under the influence of drugs, compared with $11 \%$ of FCSW. Similarly, 73\% of MSM reported having intercourse under the influence of alcohol, compared with $47 \%$ of FCSW participants. A history of sexually transmitted infections (STI) was reported by $37 \%$ of FCSW over the preceding 12 months. The most frequent STI reported was genital discharge (vaginal or urethral), followed by syphilis. 
Table 1 - Demographic characteristics and risk behaviour of study population, Paraguay 2002-2003.

\begin{tabular}{|c|c|c|c|c|}
\hline \multirow[b]{2}{*}{ Feature } & \multicolumn{2}{|c|}{ MSM } & \multicolumn{2}{|c|}{ FCSW } \\
\hline & $\mathrm{n}^{0}$ & $\%$ & $\mathrm{n}^{0}$ & $\%$ \\
\hline Number of subjects enrolled & \multicolumn{2}{|c|}{92} & \multicolumn{2}{|c|}{723} \\
\hline Age, mean \pm SD (years) & \multicolumn{2}{|c|}{$24.97 \pm 6.95$} & \multicolumn{2}{|c|}{$26 \pm 7.24$} \\
\hline median[range] & \multicolumn{2}{|c|}{$22[18,60]$} & \multicolumn{2}{|c|}{$24[18,66]$} \\
\hline \multicolumn{5}{|l|}{ Educational level (years) } \\
\hline no formal education & 1 & 1,1 & 27 & 3,7 \\
\hline primary $(0-6)$ & 15 & 16,3 & 452 & 62,5 \\
\hline secondary $(7-11)$ & 64 & 69,6 & 237 & 32,8 \\
\hline higher (>11) & 12 & 13,0 & 6 & 0,8 \\
\hline \multicolumn{5}{|l|}{ Nationality } \\
\hline paraguayan & 89 & 96,7 & 686 & 94,9 \\
\hline brazilian & 1 & 1,1 & 32 & 4,4 \\
\hline argentinian & 2 & 2,2 & 2 & 0,3 \\
\hline other South American countries & 0 & & 3 & 0,4 \\
\hline \multicolumn{5}{|l|}{ Marital status } \\
\hline single & 74 & 80,4 & 474 & 65,6 \\
\hline married & 3 & 3,3 & 16 & 2,2 \\
\hline concubine & 6 & 6,5 & 147 & 20,3 \\
\hline separated/divorced & 5 & 5,4 & 56 & 7,7 \\
\hline widower & 1 & 1,1 & 14 & 1,9 \\
\hline no answer & 3 & 3,3 & 16 & 2,2 \\
\hline \multicolumn{5}{|c|}{ Sexual intercourse with (\# persons per week) } \\
\hline $1-5$ & 30 & 32,6 & 252 & 34,9 \\
\hline $6-10$ & 23 & 25,0 & 272 & 37,6 \\
\hline $11-20$ & 18 & 19,6 & 170 & 23,5 \\
\hline No answer & 21 & 22,8 & 29 & 4,0 \\
\hline Steady partner currently & 35 & 38,0 & 306 & 42,3 \\
\hline \multicolumn{5}{|c|}{ Use of condoms with regular partner } \\
\hline never & 21 & 22,8 & 472 & 65,3 \\
\hline sometimes & 12 & 13,0 & 62 & 8,6 \\
\hline always & 8 & 8,7 & 45 & 6,2 \\
\hline no answer & 51 & 55,4 & 144 & 19,9 \\
\hline \multicolumn{5}{|c|}{ Use of condoms with occasional partners } \\
\hline never & 7 & 7,6 & 34 & 4,7 \\
\hline sometimes & 53 & 57,6 & 221 & 30,6 \\
\hline always & 26 & 28,3 & 460 & 63,6 \\
\hline no answer & 6 & 6,5 & 8 & 1,1 \\
\hline \multicolumn{5}{|c|}{ Sexual intercourse under the effects of alcohol } \\
\hline never & 13 & 14,1 & 225 & 31,1 \\
\hline sometimes & 67 & 72,8 & 341 & 47,2 \\
\hline always & 6 & 6,5 & 106 & 14,7 \\
\hline no answer & 6 & 6,5 & 51 & 7,1 \\
\hline Drug users (yes) & 45 & 48,9 & 120 & 16,6 \\
\hline marijuana & 38 & 41,3 & 94 & 13,0 \\
\hline cocaine & 24 & 26,1 & 49 & 6,8 \\
\hline intravenous & 3 & 3,3 & 5 & 0,7 \\
\hline other drugs & 10 & 10,9 & 23 & 3,2 \\
\hline \multicolumn{5}{|c|}{ Sexual intercourse under the effects of drugs } \\
\hline never & 6 & 6,5 & 27 & 3,7 \\
\hline sometimes & 36 & 39,1 & 80 & 11,1 \\
\hline always & 0 & & 5 & 0,7 \\
\hline no answer & 3 & 3,3 & 8 & 1,1 \\
\hline denies drug use & 47 & 51,1 & 603 & 83,4 \\
\hline \multicolumn{5}{|l|}{ Sexual Transmited Infection during } \\
\hline the last 12 months (yes) & 38 & 41,3 & 265 & 36,7 \\
\hline HIV Western Blot positive & 12 & 13,0 & 20 & 2,8 \\
\hline
\end{tabular}

MSM: men who have sex with other men, FCSW: female commercial sexual workers; SD Standard deviation. Total denominator varied slightly due to missing data
Risk factor analysis. Tables 2 and 3 show the analyses of risk factors for MSM and FCSW, respectively. Among FCSW, the risk factor for STI over the preceding year was 2.52 times higher than among those without a history of STI $(\mathrm{CI}=1.00-6.40$; $\mathrm{p}=0.052$ ). Among MSM participants, cocaine use was associated with increased risk of HIV acquisition, with an AOR of 6.61 $(\mathrm{CI}=1.72-25.45 ; \mathrm{p}=0.006)$ in multiple analyses.

Table 2 - Adjusted odds ratio risk factors for HIV infection among 92 men who have sex with men Paraguay, 2002-2003.

\begin{tabular}{lccc}
\hline Feature & AOR & $\begin{array}{c}\text { Multiple Analysis } \\
(95 \% \mathrm{CI})\end{array}$ & P-value \\
\hline Sexual partners per week & & & \\
$\quad$ two or three (none or one) & 1.62 & $(0.21-12.66)$ & 0.648 \\
$\quad$ four or more (none or one) & 2.82 & $(0.55-14.51)$ & 0.215 \\
Sexually-transmitted infection (last year) & 1.52 & $(0.45-5.14)$ & 0.505 \\
Sexual contact with foreigners & 1.01 & $(0.92-1.10)$ & 0.319 \\
Marijuana use & 2.22 & $(0.63-7.84)$ & 0.217 \\
Intravenous drug use & 2.33 & $(0.22-24.40)$ & 0.481 \\
Cocaine use & 6.61 & $(1.72-25.45)$ & 0.006 \\
\hline
\end{tabular}

AOR: adjusted odds ratio for age in years.

95\% CI $=95 \%$ confidence interval on AOR. The categories in parenthesis describe the reference group for odds calculation.

Table 3 - Adjusted odds ratio (AOR) risk factors for HIV infection among 723 female commercial sex workers in Paraguay, 2002-2003.

\begin{tabular}{|c|c|c|c|}
\hline \multirow[b]{2}{*}{ Feature } & \multicolumn{3}{|c|}{ Multiple analysis } \\
\hline & $\mathrm{AOR}^{*}$ & $(95 \% \mathrm{CI})$ & p-value \\
\hline \multicolumn{4}{|l|}{ Age (years) } \\
\hline$<25$ & 1,94 & $(0.73-5.16)$ & 0.186 \\
\hline \multicolumn{4}{|l|}{ Education } \\
\hline none, primary & 1,55 & $(0.56-4.35)$ & 0.401 \\
\hline \multicolumn{4}{|l|}{ Marital status single } \\
\hline yes & 1,96 & $(0.63-6.05)$ & 0.244 \\
\hline \multicolumn{4}{|l|}{ Work on the street } \\
\hline yes & 1,99 & $(0.81-4.88)$ & 0.135 \\
\hline \multicolumn{4}{|l|}{ Monthly income } \\
\hline$<600,000$ guaranies ( US\$115) & 2,56 & $(0.94-6.99)$ & 0.066 \\
\hline Clients per week $>=5$ & 0,79 & $(0.30-2.11)$ & 0.638 \\
\hline \multicolumn{4}{|l|}{ condom always used with clients } \\
\hline no & 1,97 & $(0.79-4.93)$ & 0.146 \\
\hline \multicolumn{4}{|l|}{ oral sex with clients } \\
\hline yes & 1,97 & $(0.76-5.09)$ & 0.163 \\
\hline \multicolumn{4}{|l|}{ condom use in the last sexual contact } \\
\hline \multicolumn{4}{|l|}{ yes } \\
\hline no & 1,77 & $(0.56-5.57)$ & 0.333 \\
\hline \multicolumn{4}{|c|}{ drugs used (marijuana, heroin or cocaine use) } \\
\hline yes & 0,86 & $(0.24-3.06)$ & 0.817 \\
\hline \multicolumn{4}{|l|}{ sexual contacts with foreigners } \\
\hline yes & 1,73 & $(0.49-6.17)$ & 0.396 \\
\hline \multicolumn{4}{|l|}{ any STI in the last year } \\
\hline yes & 2,52 & $(0.99-6.40)$ & 0.052 \\
\hline \multicolumn{4}{|c|}{ accept more money to allow clients not to use condom } \\
\hline yes & 1,94 & $(0.77-4.89)$ & 0.161 \\
\hline \multicolumn{4}{|c|}{ knowledge of the risk of AIDS transmission } \\
\hline \multicolumn{4}{|c|}{ wearing condoms to protect from AIDS } \\
\hline yes & 1,76 & $(0.63-4.93)$ & 0.285 \\
\hline
\end{tabular}

(AOR)adjusted odds ratio. * OR adjusted for gender, education, marital status and work on the street. $95 \% \mathrm{CI}=95 \%$ confidence interval on AOR.

The categories in parentheses describe the reference group for odds calculation. 
Genotyping. A total of 130 samples were analyzed using $e n v$ HMA and, of these, 55 were further analyzed by partial $p o l$ sequencing and 15 by full-length sequencing. The genotyping results from this study are presented in Table 4. Based on the combination of $e n v$ HMA and sequencing, HIV-1 subtype B predominated in our sample, representing 86 (66\%) of the HIVpositive samples genotyped. Envelope subtype $\mathrm{F}$ was the strain in $29(22 \%)$ of these individuals and five samples (3.9\%) were found to be subtype $\mathrm{C}$. When the partial pol sequences were examined phylogenetically, $20 \%$ of the sequenced strains were $\mathrm{BF}$ recombinants (Figure 2). Because the env gene in most of the $\mathrm{BF}$ recombinants were subtype $F$, many of the strains that were found to be subtype F by $e n v$ HMA were found to be BF recombinants by partial $p o l$ sequencing.

Table 4 - Summary of the HIV subtypes in Paraguay presented by group. 2002-2003

\begin{tabular}{|c|c|c|c|c|c|c|c|c|c|c|c|}
\hline & \multicolumn{2}{|c|}{ Total } & \multicolumn{2}{|c|}{ HIV } & \multicolumn{2}{|c|}{ Total genotyping } & \multicolumn{5}{|c|}{ Genotypes HMA/ProRT/full length } \\
\hline & count & $\%$ & count & $\%$ & count & $\%$ & B & CRF12_BF & C & CRF17_BF & $\mathrm{F}$ \\
\hline \multicolumn{12}{|l|}{ By Group } \\
\hline HIV (+) & 120 & 12.8 & 120 & 100.0 & 111 & 92.5 & 80 & 8 & 1 & 2 & 20 \\
\hline MSM & 92 & 9.8 & 12 & 13.0 & 7 & 58.3 & 1 & - & 3 & - & 3 \\
\hline FCSW & 723 & 77.3 & 20 & 2.8 & 12 & 60.0 & 5 & - & 1 & - & 6 \\
\hline$\overline{\text { Total }}$ & 935 & 100.0 & 152 & 16.3 & 130 & 85.5 & 86 & 8 & 5 & 2 & 29 \\
\hline
\end{tabular}

Some samples had unknown results from HMA. These samples need further investigation.

HIV: Human immunodeficiency virus; HMA: heteroduplex mobility assay; B, BF, C: HIV subtypes; CRF: circulating recombinant form. MSM: men who have sex with other men. FCSW: Female commercial sexual worker.

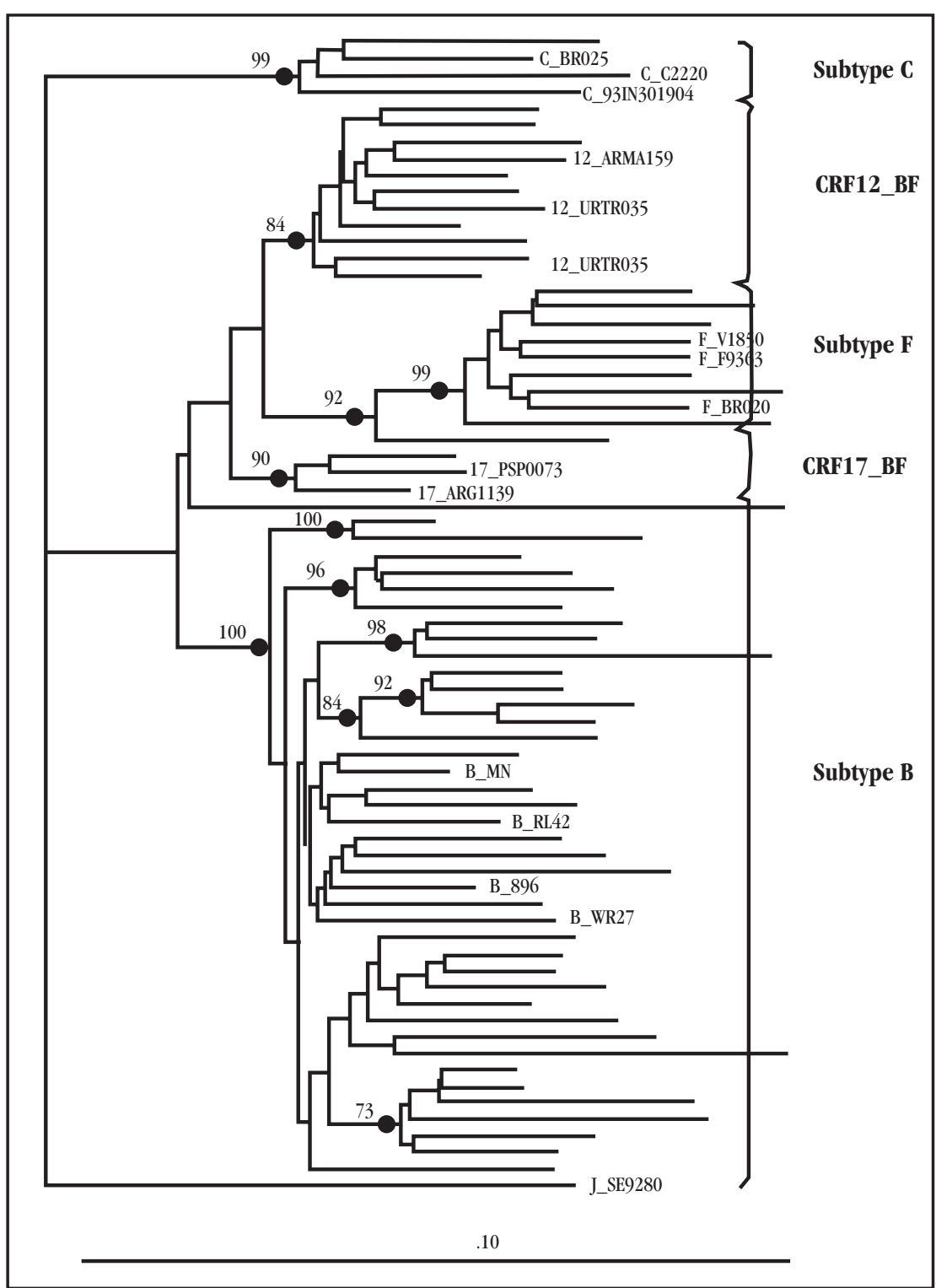

Figure 2 - HIV Phylogenetic Tree. Paraguay 2004-2005. Phylogenetic analyses of partial polymerase gene sequences from 55 HIV(+) patients from Paraguay - Sequences were analyzed by neighbor-joining and bootstrap values by parsimony. Phylogenetic tree has reference strains (name proceded by subtype) and Paraguayan strains (no name next to the branch). Branch lengths are proportional to genetic distance with scale bar at the bottom. 


\section{DISCUSSION}

Although the prevalence of HIV infection among the general population of Paraguay is low, there remain behavioral risk factors associated with increased susceptibility in certain vulnerable groups. As in other countries, men who have sex with men and female commercial sex workers are at a higher risk of HIV acquisition.

The National AIDS/STI Control Program developed this study specifically to determine the prevalence of HIV infection and its genetic sub-types circulating among selected risk groups. No previous analyses of the HIV epidemic in Paraguay based on nationwide surveys existed, and our sample size was obtained based on the estimated prevalence for the country. The sample size is not representative of each participating city.

This study was performed in five selected Paraguayan cities where HIV had previously been found to be endemic. Their proximity to border areas with high concentrations of commercial activities and population movements may have contributed towards the spread of HIV in this country, as has been suggested elsewhere $^{12}$

Both of our groups were young and predominantly unmarried. A low level of education was noted among FCSW, with elementary school completion as the highest level of education attained among more than half of the group, compared with an average attainment of high-school education among MSM.

Both groups reported high numbers of sexual partners: over $40 \%$ of MSM and over $60 \%$ of FCSW described having six or more sexual partners per week. The use of barrier protection was variable but nonetheless low in both populations. FCSW reported somewhat higher rates of condom use with occasional partners (63\%) than did MSM (28.3\%), but the overall use of barrier protection remained less than ideal. Consistent use of condoms with regular partners was even lower, both among MSM and among FCSW (8.7\% and 6.2\%, respectively). Given the high number of multiple partners in both groups, this was likely to represent a major route for HIV transmission.

Illegal drug use was also common in both groups, and marijuana and cocaine were the most frequently used illegal drugs. Injection drug use was fairly rare in both populations (3.3\% in MSM, $0.7 \%$ in FCSW), suggesting that this may be a lesser contributor to the spread of HIV in Paraguay. Despite this, cocaine use by MSM was significantly associated with increased risk of HIV acquisition during the study period (AOR $=6.61$; $95 \% \mathrm{CI}=1.72-25.45)$. Whether this increased risk was related to percutaneous transmission or associated with high-risk behavior was unclear. Overall, intravenous drug use was roughly three times more common among MSM than FCSW, as were alcohol use and histories of sexual intercourse under the influence of alcohol and/or drugs.

Although FCSW had more protective attitudes against HIV, condom use was low among FCSW and very low among MSM. FCSW used condoms especially with their occasional partners and less frequently with their steady partners. A history of STI over the previous year was reported more frequently by MSM than by FCSW, with urethral and vaginal discharge as the most frequently reported syndromes in the respective groups. Despite the greater prevalence of reported STI, we did not find any association with HIV among MSM. There was an increased risk of HIV acquisition among FCSW with a recent history of another STI (AOR $=2.52 ; 95 \%$ $\mathrm{CI}=0.99-6.40 ; \mathrm{p}=0.052$ ).

The HIV/AIDS epidemic in Paraguay is concentrated in highrisk populations such as MSM and FCSW who have risk sexual behavior ${ }^{9}$. In this study, the prevalence of HIV cases was high among MSM and intermediate to high among FCSW. It was greater than that of the general population in both groups.

Analyzing the results according to the risk factors found, we can surmise that the epidemic among women is more related to sex than to injection drug use or other risk associations. The high prevalence of HIV infections among MSM may be related to the high rates of illegal drug use. We evaluated particular sexual practices in our study, but further investigation might delineate the types of high-risk behavior among Paraguayan MSM more precisely. We also did not seek to correlate the frequency of condom use with the number of sexual partners. Lower rates of condom use among MSM with greater numbers of sexual partners, for example, would support an even greater role for sexual transmission in this group.

Further research is needed to study the use of illicit substances in these populations in greater depth, along with the link between using these substances and HIV infection.

Regarding knowledge of the risk of AIDS transmission, a high percentage $(86 \%)$ of the FCSW knew that wearing condoms would reduce the risk of AIDS transmission but, nonetheless, they accepted more money to allow clients not to use condoms. In addition, FCSW knew that avoiding receiving blood transfusions would protect them from AIDS, but only a low percentage knew that avoiding sharing needles and syringes would reduce the risk of transmission. This may have been related to the lower lever of education documented among FCSW. This suggests that there is a need for better information about HIV transmission via needle/syringe sharing.

Our analysis of HIV-1 clades confirms the notion that genetic distribution is a dynamic process. The generation and discovery of several unique recombinants raises the possibility that reinfections with viruses of differing clades may not be a rare event. This could be important with regard to possible vaccine design and efficacy. In Paraguay, there are a high number of clade $\mathrm{C}, \mathrm{F}$ and $\mathrm{B} / \mathrm{F}$ recombinants. This differs from the previous description of clade $B$ predominance noted in other South American countries ${ }^{710}$. The molecular characteristics of a CRF17_BF recombinant have been found in Paraguay but this will be reported in greater depth in a future paper.

In our study, the $\mathrm{C}$ subtype was reported in $4 \%$ and the proximity of the localities in this study to southern Brazil, where subtypes $\mathrm{C}$ and $\mathrm{F}$ have been reported, could explain this finding. This suggests possible cross-border transmission and may have public health implications for Brazil and Paraguay alike.

Our findings provide important information for monitoring the transmission of HIV-1 strains among different groups at 
risk in Paraguay. The epidemic in Paraguay is still considered a concentrated epidemic (i.e. the prevalence of HIV is $<1 \%$ in the general population) but, unlike the epidemics in the Andean countries to the west, there is a higher relative prevalence of non-B subtypes in Paraguay. In Argentina, Uruguay and Brazil, genetic diversity of HIV has historically been associated with spread into the general population. It should be a matter of concern that this may prove to be the case in Paraguay as well.

Disclaimer: This work was supported by Work Unit Number (WUN) No. 62787A.873.H.B0002. The views expressed in this article are those of the author and do not necessarily reflect the official policy or position of the Department of the Navy, Department of Defense, nor the US Government. Copyright statement: Some of the authors are employees of the US Government. This work was prepared as part of their official duties. Title 17 U.S.C. $\$ 105$ provides that 'Copyright protection under this title is not available for any work of the United States Government.' Title 17 U.S.C. $\S 101$ defines a U.S. Government work as a work prepared by a military service member or employee of the U.S. Government as part of that person's official duties. Human Use Statement The study protocol was approved by the Ministry of Health of Paraguay and the Naval Medical Research Center Institutional Review Board (Protocol \# NMRCD.2002.0006) in compliance with all applicable Federal regulations governing the protection of human subjects.

\section{ACKNOWLEDGEMENTS}

Ms. Ruth Centeno (NMRCD) for data managing and Ms. Pamela Limo (NMRCD) for assistance with the illustrations and tables

\section{REFERENCES}

1. Carr JK, Avila, M, Gomez-Carrillo M, Salomon H, Hierholzer J, Watanaveeradej V, Pando, MA, Negrete M, Russell KL, Sanchez J, Birx DL, Andrade R, Viñoles J, McCutchan, FE. Diverse BF recombinants have spread widely since the introduction of HIV-1 into South America. AIDS 15: F41-F47, 2001.
2. Carr JK, Salminen MO, Albert J, Sanders-Buell E, Gotte, D, Birx, DL, McCutchan, FE. Full genome sequences of human immunodeficiency virus type 1 subtypes $\mathrm{G}$ and $\mathrm{A} / \mathrm{G}$ intersubtype recombinants. Virology 247: 22-31, 1998.

3. Carr JK, Salminen MO, Koch C, Gotte D, Artenstein AW, Hegerich PA, St Louis D, Burke DS, McCutchan FE. Full-length sequence and mosaic structure of a human immunodeficiency virus type 1 isolate from Thailand. Full-length sequence and mosaic structure of a human immunodeficiency virus type 1 isolate from Thailand. Journal of Virology 70:5935-5943, 1996.

4. Carrion G, Eyzaquirre L, Montano S, Laguna-Torres VA, Serra M, Aguayo N, Avila M, Ruchansky D, Pando MA, Vinoles J, Perez J, Barboza A, Chauca G, Romero A, Galeano A, Blair P, Weissenbacher M, Birx D, Sanchez JL, Olson JG, Carr JK. Documentation of Subtype C HIV Type 1 Strains in Argentina, Paraguay and Uruguay. AIDS Research Human Retroviruses 20: 1022-1025, 2004.

5. Carrion G, Hierholser J. Montano S, Alava A, Perez J, Guevara A, Laguna-Torres VA, Mosquera C, Russell K, Cruz C, Chauca G, Kochel T, Birx L, Sanchez JL, Carr JK. Circulating recombinant form CRF02_AG in South America. AIDS Res Hum Retroviruses 19: 329-32, 2003.

6. Galeano Adolfo. Los primeros diez casos de SIDA en el Paraguay. Tesis Doctoral. Universidad Nacional de Asunción. 1989.

7. Laguna-Torres VA, Olson J, Sánchez JL, Montano S, Chauca G, Carrion G, Romero A, Rios J, Gamero ME, Sovero M, Perez-Bao J, Carr JK. Distribución de los subtipos del VIH-1 en nueve países de America del Sur, 1995-2002. Revista Peruana de Medicina Experimental y Salud Publica, 22:12-18, 2005.

8. Martinez AM, Barbosa E, Ferreira P, Cardoso F, Silveira J, Silva C, Mendonça-Signorini V, Antunes C. Molecular epidemiology of HIV-1 in Rio Grande do Sul, Brazil. Revista da Sociedade Brasileira de Medicina Tropical 35: 471-476, 2002.

9. Ministerio de Salud del Paraguay, Situación VIH/SIDA 2005. Reporte Anual del Programa Nacional de SIDA (PRONASIDA) Asunción, 2005

10. Montano SM, Sanchez JL, Laguna-Torres VA, Cuchi P, Avila MM, Weissenbacher M, Serra M, Vinoles J, Russi JC, Aguayo N, Galeano AH, Gianella A, Andrade R, Arredondo A, Ramirez E, Acosta ME, Alava A, Montoya 0, Guevara A, Manrique H, Sanchez JL, Lama JR, de la Hoz F, Sanchez GI, Ayala C, Pacheco ME, Carrion G, Chauca G, Perez JJ, Negrete M, Russell KL, Bautista CT, Olson JG, Watts DM, Birx DL, Carr JK, South American HIV Molecular Surveillance Working Group. Prevalences, genotypes, and risk factors for HIV transmission in South America. Journal of Acquired Immune Deficiency Syndrome 40: 57-64, 2005.

11. Salminen MO, Carr JK, Robertson DL, Hegerich P, Gotte D, Koch C., Sanders-Buell E, Gao F, Sharp PM, Hahn BH, Burke DS, McCutchan FE. Evolution and probable transmission of intersubtype recombinant human immunodeficiency virus type 1 in a Zambian couple. Journal of Virology 71: 2647-2655, 1997.

12. UNAIDS, Joint United Nations Programme on Acquired Immune Deficiency Syndrome. Population Mobility and AIDS. UNAIDS Technical Update. Geneva: UNAIDS, February 2001

13. Villafañe M. Perfil de VIH/SIDA en Paraguay. Informe de Consultoría. Febrero 2000. 